\title{
Curcuminoid-derived 3,5-bis(styryl)isoxazoles - Mechanochemical synthesis and antioxidant activity
}

\author{
DAISY R SHERIN* and KALLIKAT N RAJASEKHARAN \\ Department of Chemistry, University of Kerala, Kariavattom, Thiruvananthapuram 695 581, \\ Kerala, India \\ e-mail: sherindr84@gmail.com
}

MS received 25 April 2016; revised 26 May 2016; accepted 28 May 2016

\begin{abstract}
Mechanochemical synthesis of curcuminoid-derived 3,5-bis(styryl)isoxazoles and their antioxidant activities are reported.
\end{abstract}

Keywords. Curcuminoids; 3,5-bis(styryl)isoxazoles; antioxidant

\section{Introduction}

Curcumin, the active ingredient of turmeric, is a diarylheptanoid natural product that is endowed with much bioactivity; ${ }^{1-3}$ yet it has limited applications as a drug due to its low bioavailability. ${ }^{4}$ Structural modification of curcumin has been explored much as a strategy to circumvent this inadequacy. Among such structurally modified curcumin derivatives, the curcumin-derived pyrazoles and isoxazoles have been investigated extensively. ${ }^{5-13}$ With our long standing interest in the synthesis and bioactivity studies on curcumin, its analogs and derivatives, ${ }^{14-18}$ we have also investigated the structural modification approach. ${ }^{12,19}$ The natural curcumin is a mixture of three compounds, namely 1,7-bis(4-hydroxy-3-methoxyphenyl)-1,6-heptadiene-3,5-dione (1) (curcumin I), its demethoxy (curcumin II) and bisdemethoxy (curcumin III) derivatives. Recently, we have reported the rapid, mechanochemical synthesis and antioxidant assay of 3,5-bis(4-hydroxy-3-methoxystyryl) pyrazole (2a), its 1-aryl derivatives (2b) and 3,5-bis(4hydroxy-3-methoxystyryl)isoxazole (2c) prepared from curcumin I (1) ${ }^{19}$ In continuation, we have now extended the above method for the synthesis of 3,5-bis(styryl) isoxazoles (4a-g) from other, differently substituted curcuminoids (3a-g), with a view to understand how the substituents on the aryl ring would affect the antioxidant activity, in the light of the continued interest on the antioxidant activity of curcumin, its derivatives and analogs. ${ }^{20-22}$ The thermal methods that have been reported earlier for the synthesis of curcumin-derived isoxazoles take, in general, $6-40 \mathrm{~h}$ for completion. ${ }^{6-9,13}$

\footnotetext{
*For correspondence
}

\section{Experimental}

\subsection{General}

Reagents and solvents used were of analytical grade. Thin Layer Chromatography (TLC) and Preparative Thin Layer Chromatography (PTLC) were performed on glass plates $(20 \times 75 \mathrm{~mm}$ and $20 \times 20 \mathrm{~cm}$, respectively) coated with TLC grade silica gel-G (E. Merck, India). The spots or bands were visualized directly or under UV light. The $\mathrm{C}, \mathrm{H}, \mathrm{N}$ analyses were carried out on Vario EL Elementar analyzer. ${ }^{1} \mathrm{H}$ and ${ }^{13} \mathrm{C}$ NMR were recorded on Bruker Topspin and Bruker $\mathrm{AV}, 500 \mathrm{MHz}$ (500 MHz for ${ }^{1} \mathrm{H}$ and $125 \mathrm{MHz}$ for ${ }^{13} \mathrm{C}$ NMR), Bruker Avance III, $400 \mathrm{MHz}\left(400 \mathrm{MHz}\right.$ for ${ }^{1} \mathrm{H}$ and $100 \mathrm{MHz}$ for ${ }^{13} \mathrm{C}$ NMR) at room temperature. Chemical shifts are given in ppm relative to TMS as an internal standard. HRMS were recorded on JEOL JMS $600 \mathrm{H}$ mass spectrometer. The absorbance values were recorded on a Jasco V-550 spectrophotometer. The curcuminoids (3ag) were obtained from suitably substituted benzaldehydes by adopting the method reported earlier by us and their identities were established by spectral characterization and comparison with samples available with us. $^{12,14,23}$

\subsection{General procedure for the synthesis of 3,5-bis (styryl)isoxazoles (4a-g)}

A mixture of curcuminoid 3a-g $(0.1 \mathrm{mmol})$, hydroxylamine hydrochloride $(0.1 \mathrm{mmol})$ and glacial acetic acid $(0.1 \mathrm{~mL})$ were vigorously ground in an agate mortar for 1-2 mins. The crude product, obtained in a powder form, was then purified by PTLC $\left(\mathrm{CHCl}_{3}\right.$ : EtOAc, 3:2) to afford the 3,5-bis(styryl)isoxazoles (4a-g). 
2.2a 3,5-Bis(4-hydroxystyryl)isoxazole (4a): Yield 87\%; M.p. $198^{\circ} \mathrm{C} ;{ }^{1} \mathrm{H}$ NMR $\left(500 \mathrm{MHz}\right.$, Acetone-d $\left.\mathrm{d}_{6}\right): \delta 5.62$ (s, 1H, 4-H), 5.94 (s, 2H, ArOH), 6.64 (d, 2H, 2,6-H, $J=16.0 \mathrm{~Hz}), 6.86(\mathrm{~d}, 2 \mathrm{H}, \mathrm{ArH}, J=8.0 \mathrm{~Hz}), 7.14$ 7.15 (dd, 4H, ArH), 7.37 (s, 2H, ArH), 7.52 (d, 2H, $1,7-\mathrm{H}, J=16.0 \mathrm{~Hz}) ;{ }^{13} \mathrm{C}$ NMR $(100 \mathrm{MHz}$, DMSO$\left.\mathrm{d}_{6}\right): \delta 168.6,162.1,148.1,147.9,147.8,136.3,134.7$, 127.3, 126.9, 121.4, 121.2, 115.6, 115.5, 112.6, 110.4, 110.3, 110.1, 97.8; HRMS (ESI): Calcd for $\mathrm{C}_{19} \mathrm{H}_{15} \mathrm{NO}_{3}$, $(\mathrm{M}+\mathrm{H})$ : 306.11302; Found: 306.11308; Anal. Calcd. (\%) For $\mathrm{C}_{19} \mathrm{H}_{15} \mathrm{NO}_{3}$ : C, 74.74; H, 4.95; N, 4.59; Found (\%): C, 74.53; H, 5.17; N, 4.69.

2.2b 3,5-Bis(3-hydroxy-4-methoxystyryl)isoxazole (4b): Yield $85 \%$; M.p. $168^{\circ} \mathrm{C} ;{ }^{1} \mathrm{H}$ NMR $(500 \mathrm{MHz}$, Acetone$\left.\mathrm{d}_{6}\right): \delta 3.82\left(\mathrm{~s}, 6 \mathrm{H}, \mathrm{OCH}_{3}\right), 5.60(\mathrm{~s}, 1 \mathrm{H}, 4-\mathrm{H}), 5.92(\mathrm{~s}, 2 \mathrm{H}$, $\mathrm{ArOH}), 6.64$ (d, 2H, 2,6-H, $J=16.0 \mathrm{~Hz}), 6.86(\mathrm{~d}, 2 \mathrm{H}$, $\operatorname{ArH}, J=8.0 \mathrm{~Hz}), 7.14-7.16(\mathrm{dd}, 2 \mathrm{H}, \mathrm{ArH}), 7.36(\mathrm{~s}$, $2 \mathrm{H}, \mathrm{ArH}), 7.52(\mathrm{~d}, 2 \mathrm{H}, 1,7-\mathrm{H}, J=16.0 \mathrm{~Hz}) ;{ }^{13} \mathrm{C} \mathrm{NMR}$ $\left(100 \mathrm{MHz}, \mathrm{DMSO}-\mathrm{d}_{6}\right): \delta 168.3,162.1,148.1,147.9$, $147.9,147.8,136.3,134.7,127.3,126.9,121.6,121.2$, 115.6, 115.5, 112.6, 110.4, 110.3, 110.1, 97.8, 55.7, 55.6 HRMS (ESI): Calcd. for $\mathrm{C}_{21} \mathrm{H}_{19} \mathrm{NO}_{5},(\mathrm{M}+\mathrm{Na})$ : 388.11609; Found: 388.11608; Anal. Calcd. (\%) For $\mathrm{C}_{21} \mathrm{H}_{19} \mathrm{NO}_{5}$ : C, 69.03; H, 5.24; N, 3.83; Found (\%): C, 68.98; H, 5.28; N, 3.96.

2.2c 3,5-Bis(2-hydroxystyryl)isoxazole (4c): Yield 84\%; M.p. $152{ }^{\circ} \mathrm{C} ;{ }^{1} \mathrm{H}$ NMR $\left(500 \mathrm{MHz}\right.$, Acetone- $\left.\mathrm{d}_{6}\right): \delta 5.64$ (s, 1H, 4-H), 5.97 (s, 2H, ArOH), 6.64 (d, 2H, 2,6-H, $J=16.0 \mathrm{~Hz}), 6.85(\mathrm{~d}, 2 \mathrm{H}, \mathrm{ArH}, J=8.0 \mathrm{~Hz}), 7.14-$ 7.15 (dd, 4H, ArH), 7.37 (s, 2H, ArH), 7.52 (d, 2H, 1,7$\mathrm{H}, J=16.0 \mathrm{~Hz}) ;{ }^{13} \mathrm{C}$ NMR $\left(100 \mathrm{MHz}\right.$, DMSO-d $\left.\mathrm{d}_{6}\right): \delta$ 168.9, 162.1, 148.3, 147.9, 147.8, 147.6, 136.1, 134.7, $127.6,126.9,121.4,121.2,115.5,115.3,112.8,110.4$, 110.3, 110.1, 97.6; HRMS (ESI): Calcd for $\mathrm{C}_{19} \mathrm{H}_{15} \mathrm{NO}_{3}$, $(\mathrm{M}+\mathrm{H})$ : 306.11302; Found: 306.11306; Anal. Calcd. (\%) For $\mathrm{C}_{19} \mathrm{H}_{15} \mathrm{NO}_{3}$ : C, 74.74; H, 4.95; N, 4.59; Found (\%): C, 74.51; H, 5.12; N, 4.66.

$2.2 \mathrm{~d}$ 3,5-Bis(4-methoxystyryl)isoxazole (4d): Yield 85\%; M.p. $143{ }^{\circ} \mathrm{C}$; ${ }^{1} \mathrm{H}$ NMR $\left(500 \mathrm{MHz}\right.$, Acetone- $\left.\mathrm{d}_{6}\right): \delta 3.84$ $\left(\mathrm{s}, 6 \mathrm{H}, \mathrm{OCH}_{3}\right), 5.64(\mathrm{~s}, 1 \mathrm{H}, 4-\mathrm{H}), 6.64(\mathrm{~d}, 2 \mathrm{H}, 2,6-\mathrm{H}$, $J=16.0 \mathrm{~Hz}), 6.86(\mathrm{~d}, 2 \mathrm{H}, \mathrm{ArH}, J=8.0 \mathrm{~Hz}), 7.14-$ 7.15 (dd, 4H, ArH), 7.36 (s, 2H, ArH), 7.52 (d, 2H, $1,7-\mathrm{H}, J=16.0 \mathrm{~Hz}) ;{ }^{13} \mathrm{C}$ NMR $(100 \mathrm{MHz}, \mathrm{DMSO}-$ $\left.\mathrm{d}_{6}\right): \delta 168.7,162.9,148.1,147.9,147.8,136.3,134.3$, 127.3, 126.1, 121.6, 121.2, 115.6, 115.4, 112.6, 110.5, 110.3, 110.1, 55.71, 55.67; HRMS (ESI): Calcd for $\mathrm{C}_{21} \mathrm{H}_{19} \mathrm{NO}_{3}$, $(\mathrm{M}+\mathrm{Na})$ : 356.12626; Found: 356.12628; Anal. Calcd. (\%) For $\mathrm{C}_{21} \mathrm{H}_{19} \mathrm{NO}_{3}$ : C, 75.66; H, 5.74; N, 4.20; Found (\%): C, 75.52; H, 5.79; N, 4.06 . 2.2e 3,5-Bis(3,4-dimethoxystyryl)isoxazole (4e): Yield $82 \%$; M.p. $16^{\circ} \mathrm{C} ;{ }^{1} \mathrm{H}$ NMR $\left(500 \mathrm{MHz}\right.$, Acetone-d $\left.\mathrm{d}_{6}\right): \delta$ $3.84\left(\mathrm{~s}, 12 \mathrm{H}, \mathrm{OCH}_{3}\right), 5.64(\mathrm{~s}, 1 \mathrm{H}, 4-\mathrm{H}), 6.64(\mathrm{~d}, 2 \mathrm{H}$, $2,6-\mathrm{H}, J=16.0 \mathrm{~Hz}), 6.86(\mathrm{~d}, 2 \mathrm{H}, \mathrm{ArH}, J=8.0 \mathrm{~Hz})$, 7.14-7.15 (dd, 2H, ArH), 7.36 (s, 2H, ArH), 7.52 (d, 2H, $1,7-\mathrm{H}, J=16.0 \mathrm{~Hz}) ;{ }^{13} \mathrm{C}$ NMR $(100 \mathrm{MHz}$, DMSO-d 6 ): $\delta 168.9,162.1,148.3,147.9,147.1,136.7,134.3,127.3$, 126.8, 121.5, 121.2, 115.6, 115.4, 112.6, 110.6, 110.3, 110.1, 55.7, 55.6HRMS (ESI): Calcd for $\mathrm{C}_{23} \mathrm{H}_{23} \mathrm{NO}_{5}$, (M+Na): 416.14739; Found: 416.14736; Anal. Calcd. (\%) For $\mathrm{C}_{23} \mathrm{H}_{23} \mathrm{NO}_{5}$ : C, 70.21; $\mathrm{H}, 5.89 ; \mathrm{N}, 3.56$; Found (\%): C, 70.06; H, 6.13; N, 3.83 .

2.2f 3,5-Bis(3,4-methylenedioxystyryl)isoxazole (4f): Yield $82 \%$; M.p. $152{ }^{\circ} \mathrm{C} ;{ }^{1} \mathrm{H}$ NMR $(500 \mathrm{MHz}$, Acetone$\left.\mathrm{d}_{6}\right): \delta 5.55(\mathrm{~s}, 1 \mathrm{H}, 4-\mathrm{H}), 5.99\left(\mathrm{~s}, 4 \mathrm{H}, \mathrm{CH}_{2}\right), 6.59(\mathrm{~d}$, $2 \mathrm{H}, 2,6-\mathrm{H}, J=16.0 \mathrm{~Hz}), 6.90(\mathrm{~s}, 2 \mathrm{H}, \mathrm{ArH}), 7.11$ $(\mathrm{m}, 4 \mathrm{H}, \mathrm{ArH}), 7.52(\mathrm{~d}, 2 \mathrm{H}, 1,7-\mathrm{H}, J=15.5 \mathrm{~Hz})$; ${ }^{13} \mathrm{C}$ NMR $\left(125 \mathrm{MHz}\right.$, Acetone- $\left.\mathrm{d}_{6}\right): \delta 150.1,148.6$, 141.8, 128.1, 123.6, 122.3, 116.2, 111.1, 106.5, 92.6, 91.5; HRMS (ESI): Calcd for $\mathrm{C}_{21} \mathrm{H}_{15} \mathrm{NO}_{5},(\mathrm{M}+\mathrm{H})$ : 362.10285; Found: 362.10286; Anal. Calcd. (\%) For $\mathrm{C}_{21} \mathrm{H}_{15} \mathrm{NO}_{5}$ : C, 69.80; H, 4.18; N, 3.88; Found (\%): C, 69.98; H, 4.39; N, 3.52 .

$2.2 \mathrm{~g} \quad$ 3,5-Bis(styryl)isoxazole (4g): Yield 83\%; M.p. $128^{\circ} \mathrm{C} ;{ }^{1} \mathrm{H}$ NMR $\left(500 \mathrm{MHz}\right.$, Acetone- $\left.\mathrm{d}_{6}\right): \delta 5.54(\mathrm{~s}$, $1 \mathrm{H}, 4-\mathrm{H}), 6.59(\mathrm{~d}, 2 \mathrm{H}, 2,6-\mathrm{H}, J=16.0 \mathrm{~Hz}), 6.90$ (s, 2H, ArH), $7.11(\mathrm{~m}, 8 \mathrm{H}, \operatorname{ArH}), 7.52(\mathrm{~d}, 2 \mathrm{H}, 1,7-$ $\mathrm{H}, J=15.5 \mathrm{~Hz}) ;{ }^{13} \mathrm{C}$ NMR $(125 \mathrm{MHz}$, Acetone$\left.\mathrm{d}_{6}\right): \delta 141.1,133.0,128.0,123.4,122.3,116.1,111.6$, 108.1; HRMS (ESI): Calcd for $\mathrm{C}_{19} \mathrm{H}_{15} \mathrm{NO},(\mathrm{M}+\mathrm{Na})$ : 296.10513; Found: 296.10511; Anal. Calcd. (\%) For $\mathrm{C}_{19} \mathrm{H}_{15} \mathrm{NO}$ : C, 83.49; H, 5.53; N, 5.12; Found (\%): C, 83.67; H, 5.75; N, 5.23.

\subsection{Antioxidant capacity assays}

2.3a DPPH assay: Methanolic solutions of 3,5-bis (styryl)isoxazoles (4a-g), at six different concentrations $(0.05,0.1,0.25,0.5,0.75$ and $1 \mathrm{mM})$, were prepared. These test solutions $(0.04 \mathrm{~mL})$ containing bis(styryl)isoxazoles (4a-g) were added to DPPH solution in methanol $\left(10^{-5} \mathrm{M} ; 2.8 \mathrm{~mL}\right)$. The absorbance was monitored at $517 \mathrm{~nm}$, after the reaction mixture was allowed to stand for $30 \mathrm{~min}$. From the absorbance values monitored, the percentage inhibition was calculated and the result is expressed in terms of $\mathrm{EC}_{50}$. The percentage of inhibition of DPPH by the antioxidant at a particular time was calculated as \% inhibition of DPPH $=\left[\left(\mathrm{Ab}_{\mathrm{c}}-\right.\right.$ $\left.\left.A b_{s}\right) / A b_{c}\right] \times 100$, where $A b_{c}$ is the absorbance of the control and $\mathrm{Ab}_{\mathrm{s}}$ is the absorbance of the sample. 
2.3b Ferric ion reducing antioxidant power (FRAP) assay: Freshly prepared FRAP reagent was used for the analysis. It was obtained by mixing acetate buffer $(300 \mathrm{mM}$ each of acetic acid and sodium acetate), tripyridyltriazine $(10 \mathrm{mM}$ in $40 \mathrm{mM}$ aqueous hydrochloric acid solution) and $\mathrm{FeCl}_{3} \cdot 6 \mathrm{H}_{2} \mathrm{O}(20 \mathrm{mM})$ aqueous solutions in the ratio 10:1:1. Methanolic solution of $\mathrm{FeSO}_{4} \cdot 6 \mathrm{H}_{2} \mathrm{O}$ was prepared at different concentrations $(0.05,0.1,0.25,0.5,0.75,1.0,1.5$ and $2.0 \mathrm{mM}$ ). The solutions of bis(styryl)isoxazoles (4ag) were also prepared in methanol $(0.5 \mathrm{mM})$ and after adding these $(0.04 \mathrm{~mL})$ to the FRAP reagent $(3 \mathrm{~mL})$, the reaction mixtures were incubated at $37^{\circ} \mathrm{C}$ for $30 \mathrm{~min}$. The absorbance was measured at $596 \mathrm{~nm}$ and the results were expressed as micro molar $\mathrm{Fe}^{2+}$ equivalents.

$2.3 \mathrm{c} \beta$-Carotene bleaching assay: $\beta$-Carotene $(0.2 \mathrm{mg})$, linoleic acid $(0.02 \mathrm{~mL})$ and Tween $20(0.18 \mathrm{~mL})$ were mixed with chloroform $(0.5 \mathrm{~mL})$ and the solvent was removed by evaporation. The residue obtained was mixed with distilled water $(50 \mathrm{~mL})$ and the resulting emulsion ( $4 \mathrm{~mL}$ aliquots each) was added to 3,5-bis(styryl)isoxazoles (4a-g) in methanol $(0.2 \mathrm{~mL}$, $1 \mathrm{mmol})$. Absorbance was measured at $470 \mathrm{~nm}$, using a mixture of the emulsion $(4 \mathrm{~mL})$ and methanol $(0.2 \mathrm{~mL})$ as the control. The absorbance was again recorded after incubation for $1 \mathrm{~h}$ at $50^{\circ} \mathrm{C}$ in the dark. The antioxidant activity (AA) was evaluated in terms of bleaching of the $\beta$-carotene using the formula $A A=\left[1-\left(\mathrm{A}_{\mathrm{o}}-\mathrm{A}_{\mathrm{t}}\right) /\left(\mathrm{A}_{\mathrm{o}}^{\mathrm{o}}-\right.\right.$ $\left.\left.A_{t}^{o}\right)\right] \times 100$, where $A_{o}$ and $A_{o}^{o}$ are the absorbance values measured at zero time of the incubation for test sample and control, respectively. $\mathrm{A}_{\mathrm{t}}$ and $\mathrm{A}_{\mathrm{t}}^{\mathrm{o}}$ are the absorbance values of the sample and control after incubation time.

\section{Results and Discussion}

\subsection{Synthesis}

The precursor curcuminoids (3a-g) were obtained by microwave assisted synthetic protocol ${ }^{23}$ by the modification of a conventional thermal method developed earlier by our group. ${ }^{14}$ Sui et al., seemingly in the first report on the synthesis of an isoxazole derivative (2c) of a curcuminoid, had reacted curcumin I (1) with hydroxylamine hydrochloride in ethanol under reflux for $16 \mathrm{~h} .{ }^{13}$ The methods subsequently reported for this reaction could be seen to generally take $6-40 \mathrm{~h}$ for the completion under conventional heating. ${ }^{5-9}$ In continuation to our work on mechanochemical synthesis of curcumin derivatives, ${ }^{19}$ we have now reacted curcuminoids (3ag) with hydroxylamine hydrochloride in presence of catalytic amount of acetic acid. The room temperature mechanical grinding in an agate mortar for about 12 minutes rapidly afforded the 3,5-bis(styryl)isoxazoles (4a-g) in powder form. We observed that the compounds obtained in better purity and yield than reported earlier, as judged by TLC. The formation and identity of these isoxazoles were confirmed by physical and spectral methods. It appears that the initially formed oxime derivatives proceeded to cyclize affording the isoxazole ring (scheme 1). Among the 3,5-bis(styryl)isoxazoles<smiles>COc1cc(/C=C/C(=O)/C=C(O)/C=C/c2ccc(O)c(OC)c2)ccc1O</smiles><smiles>COc1cc(/C=C/c2cc(/C=C/c3ccc(O)c(OC)c3)[nH]n2)ccc1O</smiles>

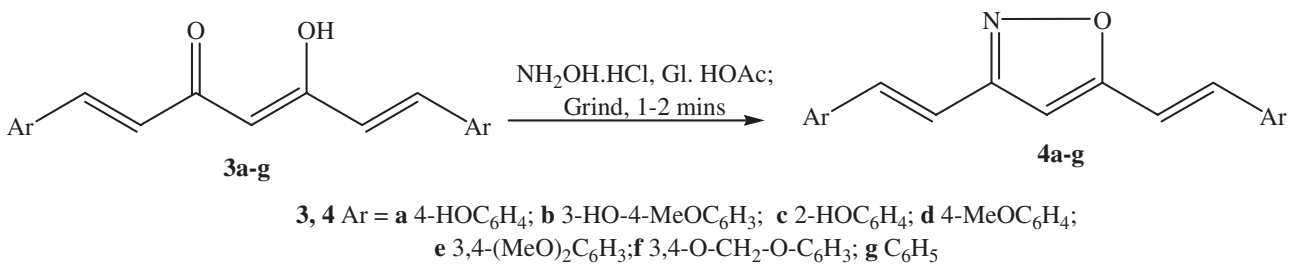

Scheme 1. Structures of curcumin I (1) and its 3,5-bis(styryl)azole derivatives. 
(4a-g) now synthesized, five examples $(\mathbf{4 b}, \mathbf{4 c}, \mathbf{4 d}, \mathbf{4 f}$ and $\mathbf{4 g}$ ) appear to be hitherto unreported.

\subsection{Antioxidant Studies}

The antioxidant (AO) activities of the 3,5-bis(styryl) isoxazoles (4a-g) were evaluated by 2,2-diphenylpicrylhydrazyl (DPPH), ferric ion reducing antioxidant power (FRAP) and $\beta$-carotene assays. The $\mathrm{AO}$ activity by the $\mathrm{DPPH}$ assay is expressed in terms of $\mathrm{EC}_{50}$ values, calculated by plotting the percentage inhibition of DPPH against various test concentrations (figure 1, table 1). We have earlier shown that the isoxazole derivative of curcumin I (2c) exhibits better AO capacity than the parent curcumin I (1) in DPPH assay under similar experimental conditions, ${ }^{19}$ the corresponding $\mathrm{EC}_{50}$ values for the percentage inhibition of DPPH being $8 \pm$ $0.011 \mu \mathrm{mol}$ and $40 \pm 0.06 \mu \mathrm{mol}$, respectively for (2c) and (1). A comparison of this data with those obtained now for the 3,5-bis(styryl)isoxazoles (4a-g) shows that the isoxazoles (4a-g) are less active than the isoxazole derivative of curcumin I (2c). However, two among these, $\mathbf{4 a}$ and $\mathbf{4 b}$, are more active than curcumin I (1). Thus, the presence of a hydroxy group juxtaposed with

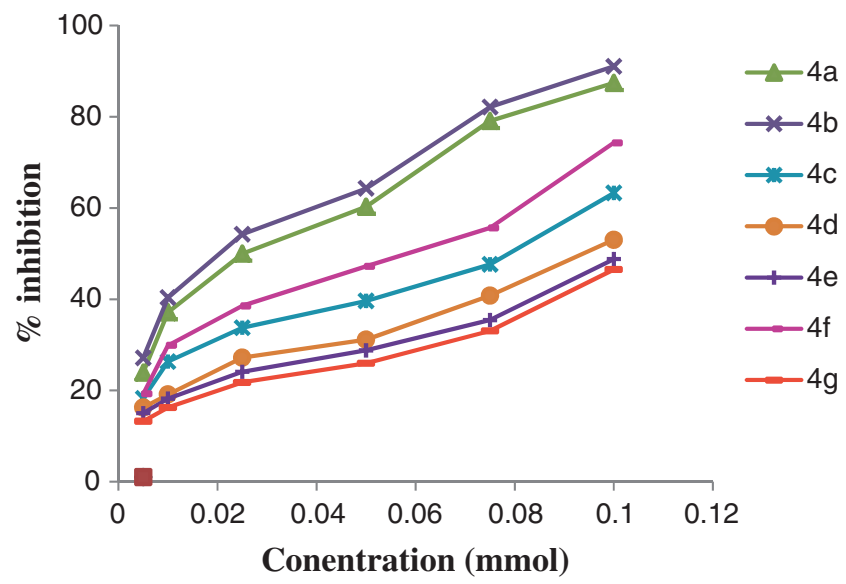

Figure 1. Percentage inhibition of DPPH $\left(10^{-2} \mathrm{mM}\right)$ at various concentrations of 3,5-bis(styryl)isoxazoles (4a-g).
Table 2. The $\mathrm{FeSO}_{4}$ equivalent of 3,5-bis(styryl)isoxazoles $(\mathbf{4 a - g})$ in the presence of FRAP reagent and the Antioxidant Activity (AA) $\%$ of $\mathbf{4 a - g}$ in $\beta$-carotene assay.

\begin{tabular}{lcc}
\hline Entry & $\mathrm{FeSO}_{4}$ equivalents $(\mu \mathrm{mol})$ & AA \% \\
\hline $\mathbf{4 a}$ & 1182 & 87.59 \\
$\mathbf{4 b}$ & 1195 & 90.91 \\
$\mathbf{4 c}$ & 997 & 76.99 \\
$\mathbf{4 d}$ & 883 & 69.52 \\
$\mathbf{4 e}$ & 592 & 65.31 \\
$\mathbf{4 f}$ & 1036 & 80.23 \\
$\mathbf{4 g}$ & 475 & 61.12 \\
\hline
\end{tabular}

a methoxy group on the terminal aryl rings enhances the $\mathrm{AO}$ activity of curcuminoid derived isoxazoles.

The results of FRAP assay are expressed as micromolar $\mathrm{Fe}^{2+}$ equivalents (table 2); a higher value of ferrous sulphate equivalent being indicative of a better $\mathrm{AO}$ capacity. Our earlier sttudies ${ }^{19}$ have shown that under identical assay conditions, the curcumin I derived isoxazole (2c) and curcumin I (1) showed $\mathrm{Fe}^{2+}$ equivalent of $1304 \mu \mathrm{mol}$ and $1164 \mu \mathrm{mol}$, respectively. The present results based on FRAP assay is now seen to follow a similar pattern as seen in the DPPH assay, wherein the presence of a hydroxy group along with a methoxy group on the terminal aryl rings is found to be beneficial. A similar conclusion could now be drawn based on the $\beta$-carotene bleaching assay of the 3,5bis(styryl)isoxazoles (4a-g) (table 2) and in the light of our earlier study. ${ }^{19}$

\section{Conclusions}

We report the synthesis of curcuminoid-derived 3,5bis(styryl)isoxazoles (4a-g) by mechanochemical grinding of the respective curcuminoid and hydroxylamine hydrochloride catalyzed by gl. acetic acid. The antioxidant studies of $\mathbf{4 a - g}$ revealed that hydroxy and methoxy groups present in the terminal aryl moieties of 3,5-bis(styryl)isoxazoles improve their anti-oxidant activity.

Table 1. Percentage inhibition of DPPH $\left(10^{-2} \mathrm{mmol}\right)$ by 3,5-bis(styryl)isoxazoles (4a-g).

\begin{tabular}{lccccccc}
\hline & \multicolumn{6}{c}{ Percentage inhibition by 3,5 -bis(styryl)pyrazoles (4a-g) at various concentrations $(\mathrm{mM})$} & \\
\cline { 2 - 7 } Entry & 0.005 & 0.01 & 0.025 & 0.05 & 0.075 & 0.1 & EC $_{50}(\mu \mathrm{mol})$ \\
\hline $\mathbf{4 a}$ & $23.91 \pm 0.21$ & $37.15 \pm 0.06$ & $49.98 \pm 0.31$ & $60.29 \pm 0.18$ & $79.08 \pm 0.12$ & $87.42 \pm 0.16$ & $28 \pm 0.19$ \\
$\mathbf{4 b}$ & $27.12 \pm 0.18$ & $40.36 \pm 0.11$ & $54.25 \pm 0.22$ & $64.29 \pm 0.37$ & $82.13 \pm 0.19$ & $91.05 \pm 0.16$ & $20 \pm 0.11$ \\
$\mathbf{4 c}$ & $18.28 \pm 0.23$ & $26.32 \pm 0.09$ & $33.74 \pm 0.16$ & $39.62 \pm 0.22$ & $47.64 \pm 0.07$ & $63.29 \pm 0.34$ & $80 \pm 0.48$ \\
$\mathbf{4 d}$ & $16.27 \pm 0.16$ & $19.11 \pm 0.23$ & $27.18 \pm 0.17$ & $31.13 \pm 0.25$ & $40.77 \pm 0.06$ & $53.02 \pm 0.14$ & $96 \pm 0.52$ \\
$\mathbf{4 e}$ & $15.03 \pm 0.29$ & $18.20 \pm 0.18$ & $24.09 \pm 0.08$ & $28.78 \pm 0.24$ & $35.43 \pm 0.17$ & $48.78 \pm 0.09$ & $102 \pm 0.49$ \\
$\mathbf{4 f}$ & $19.26 \pm 0.33$ & $29.88 \pm 0.17$ & $38.56 \pm 0.24$ & $47.23 \pm 0.29$ & $55.64 \pm 0.07$ & $74.28 \pm 0.13$ & $60 \pm 0.31$ \\
$\mathbf{4 g}$ & $13.26 \pm 0.11$ & $16.27 \pm 0.21$ & $21.78 \pm 0.09$ & $25.98 \pm 0.12$ & $33.06 \pm 0.19$ & $46.52 \pm 0.17$ & $108 \pm 0.22$ \\
\hline
\end{tabular}




\section{Acknowledgements}

SDR thanks UGC and MHRD, Govt. of India for Maulana Azad National Fellowship. KNR thanks UGC for UGC-BSR Faculty and Emeritus Fellowships. The authors also thank SAIF-STIC at CUSAT, Kochi and NIIST Trivandrum, for elemental analysis, NMR and MS spectra.

\section{References}

1. Esatbeyoglu T, Huebbe P, Ernst I M, Chin D, Wagner A E and Rimbach G 2012 Angew. Chem. Int. Ed. Engl. 51 5308

2. Gupta S C, Prasad Y, Kim J H, Patchva S, Webb L J, Priyadarsini I K and Aggarwal B B 2011 Nat. Prod. Rep. 281937

3. Teiten M-H, Eifes S, Dicato M and Diederich M 2010 Toxins 2128

4. Anand P, Kunnumakkara A B, Newman R A and Aggarwal B B 2007 Mol. Pharm. 4807

5. Narlawar R, Pickhardt M, Leuchtenberger S, Baumann K, Krause S, Dyrks T, Weggen S, Mandelkow E and Schmidt B 2008 Chem. Med. Chem. 3165

6. Mishra S, Karmodiya K, Surolia N and Surolia A 2008 Bioorg. Med. Chem. 162894

7. Changtam C, Hongmanee P and Suksamrarn A 2010 Eur. J. Med. Chem. 454446

8. Amolins M W, Peterson L B and Blagg B S J 2009 Bioorg. Med. Chem. 17360
9. Das J, Pany S, Panchal S, Majhi A and Rahman G M 2011 Bioorg. Med. Chem. 196196

10. Liu Y, Dargusch R, Maher P and Schubert D 2008 J. Neurochem. 1051336

11. Maher P, Akaishi T, Schubert D and Abe K 2010 Neurobiol. Aging 31706

12. Mayadevi M, Sherin D R, Keerthi V S, Rajasekharan K N and Omkumar R V 2012 Bioorg. Med. Chem. 20 6040

13. Sui Z, Salto R, Li J, Craik C and Montellano P R O 1993 Biorg. Med. Chem. 1415

14. Babu K V D and Rajasekharan K N 1994 Org. Prep. Procedures Intl. 26674

15. Ruby A J, Kuttan G, Babu K V D, Rajasekharan K N and Kuttan R 1995 Cancer Lett. 9479

16. Devasena T, Rajasekharan K N and Menon V P 2002 Pharmcol. Res. 4639

17. Kiran M S, Sameerkumar V B, Viji R I, Sherin G T, Rajasekharan K N and Sudhakaran P R 2008 J. Cell Physiol. 215251

18. Manju M, Sherin G T, Rajasekharan K N and Oommen O V 2009 Fish Physiol. Biochem. 35413

19. Sherin D R and Rajasekharan K N 2015 Arch. Pharm. 3481

20. Ak T and Gulcin I 2008 Chemico-Biol. Inter. 17427

21. Chakraborti S, Dhar G, Dwivedi V, Das A, Poddar A, Chakraborti G, Basu G, Chakrabarti P, Surolia A and Bhattacharyya B 2013 Biochemistry 527449

22. Puneeth H R and Chandrashekariah S A 2015 Int. J. Pharm. Pharm. Sci. 7244

23. Sherin D R, Thomas S G and Rajasekharan K N 2015 Het. Commun. 21381 